\title{
Bacteriological and physico-chemical quality of drinking water sources in a rural community of Ethiopia
}

\author{
Tsega $\mathrm{N}^{1}$, Sahile $\mathrm{S}^{2}$, ${ }^{*}$ Kibret $\mathrm{M}^{1}$, Abera $\mathrm{B}^{3}$
}

1. Department of Biology, Bahir Dar University, Science College, P. O. Box 79, Bahir Dar, Ethiopia

2. Department of Biology, College of Natural and Computational Sciences, University of Gondar, Gondar, Ethiopia.

3. Department of Microbiology, Parasitology and Immunology, College of Medicine and Health Sciences Bahir Dar University, P.O. Box 79, Bahir Dar, Ethiopia

\begin{abstract}
Background: Accesses to safe water is a universal need however, many of the world's population lack access to adequate and safe water. Consumption of water contaminated causes health risk to the public and the situation is serous in rural areas. Objectives: To assess the bacteriological and physico-chemical quality of drinking water sources in a rural community of Ethiopia.

Methods: Water samples were collected from tap, open springs, open dug wells and protected springs for bacteriological analysis of total coliforms and thermotolerant coliforms. The turbidity, $\mathrm{pH}$ and temperature were measured immediately after collection.

Results: Most drinking water sources were found to have coliform counts above the recommended national and international guidelines and had high sanitary risk scores. There was a statistically significant difference among water sources with respect to TC and TTC $(\mathrm{p}<0.05)$ and there was a statistically significant positive correlation between coliform counts and sanitary risk scores $(\mathrm{p}<0.01)$. Most water sources didn't satisfy the turbidity values recommended by WHO.

Conclusion: The water sources were heavily contaminated which suggested poor protection and sanitation practice in the water sources. Source protection strategies as well as monitoring are recommend for this community.

Key words: Coliforms; physico-chemical; rural community; water quality

African Health Sciences 2013; 13(4): 1156- 1161 http://dx.doi.org/10.4314/ahs.v13i4.42
\end{abstract}

\section{Introduction}

Accesses to safe water and sanitary means of excreta disposal are universal needs and indeed basic human rights; however, many of the world's population lack access to adequate and safe water ${ }^{1}$. Use of improved sanitation facilities is low especially in Sub-Saharan Africa and South Asia. Eight hundred eighty four million people in the world still do not get their drinking-water from improved sources; Sub-Saharan Africa accounts for over a third of that number. Fresh water has become a scarce commodity due to over exploitation and pollution. Increasing

\footnotetext{
*Corresponding author:

Mulugeta Kibret

Bahir Dar University, Science College

Department of Biology

P.O. Box 79

Bahir Dar, Ethiopia

Tel: 251-918-780300

Fax: 251-582-202025

E-mail: mulugetanig@gmail.com
}

population and its necessities have led to the deterioration of surface and sub surface water ${ }^{2}$.

The greatest risk to public health from microbes in water is associated with consumption of drinking-water that is contaminated with human and animal excreta ${ }^{3}$. Human faeces can contain a variety of intestinal pathogens which cause diseases ranging from mild gastro-enteritis to the serious dysentery, cholera and typhoid. The most predominant waterborne disease, diarrhea, has an estimated annual incidence of 4.6 billion episodes and causes 2.2 million deaths every year ${ }^{4}$. Children are the main victims of diarrhea and other faecaloral disease, and also the most likely source of infection.

Total and fecal coliforms have been enumerated from various water sources ${ }^{6}$. The presence of fecal coliforms indicates the contamination of water with fecal material than may contain pathogenic organisms. These indicator bacterial were found to be more common in unprotected water sources than protected water sources?

African Health Sciences Vol 13 Issue 4 December 2013 
Ethiopia is characterized by lower water supply and sanitation coverage. It is estimated that $62.7 \%$ of the Ethiopian population relies on unimproved water sources and more than $80 \%$ of diseases in Ethiopia are attributed to poor access to clean water and sanitation ${ }^{8}$. The problem is more serious in rural area where the majorities of the people do not have access to potable water and therefore, depend on well, stream and river water for domestic use ${ }^{1}$. In the rural area where the study was conducted, there is insufficient amount of water during the dry season and hence, people are forced to fetch water from unimproved sources, travelling $2 \mathrm{~km}$ away from their homes. Even though certain households have pit latrines, they are poorly constructed and many people practice open defecation in places including those nearby the water sources.. There is also intensive farming in the area and farmers introduce domestic animals in the field where drinking water are available. There is also no proper damping of animal wastes. Garbage and liquid waste are disposed in the surrounding field as well. These situations may lead to contamination of water sources.

Five hundred ninety one diarrheal cases were reported in the study area from July to December 2011. Among these, 305 were children (Personal Communication with District Health Officer). Despite these health hazards, no study has been done on the bacteriological and physico-chemical quality of waters in this area. Hence, the aim of this study was to analyze the bacteriological and physicochemical quality of drinking water from seven different water sources found in the rural areas of Northwest Ethiopia.

\section{Methods \\ Description of the study area}

The study was conducted in rural part of Northwest Ethiopia located $810 \mathrm{Km}$ from the capital Addis Ababa. The area is located between $12^{\circ} 27^{\prime} 37^{1 / 2}$ $12^{\circ} 38^{\prime} 27^{1 / 2}$ North latitude and $36^{\circ} 57^{\prime} 30^{1 / 2}$ $37^{\circ} 10^{\prime} 06^{1 / 2}$ East longitude with an elevation range between $1860-2240 \mathrm{~m}$ above sea level.

\section{Water sampling and analysis}

A cross sectional prospective study was conducted in rural areas of Northwest Ethiopia from November 2011 to February 2012 to assess the bacteriological and physic-chemical quality of water. A total of 53 water samples were collected from four sources namely: tap, protected dug well, open dug well and open spring. For bacteriological analysis,
$250 \mathrm{ml}$ of water sample was collected between 8:30 and 10:30 am with sterile glass bottle and transported to the laboratory in ice box. The number of total coliforms and thermotolerant coliforms was determined with the membrane filtration methods using Lauryl Sulfate-Broth (Blulux laboratories Ltd, India) ${ }^{9}$. For the determination of total coliforms and thermotolerant coliforms, incubation was carried out at $37^{\circ} \mathrm{C}$ and $44^{\circ} \mathrm{C}$, respectively. Bacteriological analysis was done in triplicate within three hours of collection.

Temperature and $\mathrm{pH}$ were measured using WE30200 microprocessor; whereas, turbidity was measured using WE30140 potable turbidimeter (Singapore). Free residual chlorine, for 16 chlorinated water samples were determined using Wagtech comparator - Disc CD 109 with DPD number 1 chlorine tablets. All physico-chemical parameters were measured on site. Sanitary inspection of the water sources was also carried out using standard sanitary inspection formats and procedures ${ }^{4}$.

\section{Data analysis}

Data were entered, cleaned and analyzed using SPSS statistical package version 16.0. One way ANOVA was used to test if there are statistical differences in the tested parameters among the water sources. Spearman's correlation was used to check if there is correlation between bacteriological and physicochemical parameters. The results of bacteriological and physicochemical analyses were compared with national and WHO guidelines for drinking water. P-value $<0.05$ was considered to indicate statistically significant association.

\section{Results}

All open springs and open dug wells, 63.6\% of protected dug wells and $30 \%$ of the tap water samples had total coliform counts above the national and WHO recommended limits. Similarly $72.8 \%$ of open springs, $63.7 \%$ of open dug wells and $36.4 \%$ of protected springs had thermotolerant coliform counts above the recommended national and international guidelines (table 1).

All open dug wells and open springs were at high risk category for total coliforms and the majority of open dug wells and $27 \%$ of protected dug wells and $20 \%$ tap water had high risk categories for total coliforms. Four water samples from each of protected dug wells and open dug wells had medium risk categories for total coliforms. Regarding thermotolerant colifroms, $6(54.5 \%)$ and 4 $(36.4 \%)$ of open springs and open dug wells respectively had high risk categories (table 2). 
Table 1: Comparison of the bacteriological quality of four sources of water in rural Ethiopia

\begin{tabular}{|c|c|c|c|c|c|}
\hline \multirow{2}{*}{$\begin{array}{l}\text { Recommended levels } \\
\text { of parameters }\end{array}$} & \multirow[b]{2}{*}{ Tap $(n=20)$} & \multicolumn{3}{|l|}{ Results } & \multirow[b]{2}{*}{$\mathrm{P}=$ value } \\
\hline & & Protected dug & Open dug & Open spring & \\
\hline \multirow{2}{*}{ TC counts $/ 100 \mathrm{ml}$} & & & & & 0.001 \\
\hline & & well $(n=11)$ & well $(n=11)$ & $(n=11)$ & \\
\hline 0 & $9(45 \%)$ & - & - & - & \\
\hline $0.01-1.01$ & $1(5 \%)$ & $1(9.1 \%)$ & - & - & \\
\hline $1.01-9.99$ & $4(20 \%)$ & $3(27.3 \%)$ & - & - & \\
\hline $10-100$ & $6(30 \%)$ & $5(45.5 \%)$ & $8(72.7 \%)$ & $6(54.5 \%)$ & \\
\hline$>100$ & - & $2(18.2 \%)$ & $3(27.3 \%)$ & $5(45.5 \%)$ & \\
\hline \multicolumn{2}{|l|}{ TTC counts $/ 100 \mathrm{ml}$} & & & & 0.004 \\
\hline 0 & $20(100 \%)$ & $7(63.6 \%)$ & $4(36.4 \%)$ & $3(27.3 \%)$ & \\
\hline $0.01-1.01$ & - & $3(27.3 \%)$ & $3(27.3 \%)$ & - & \\
\hline $1.01-9.99$ & - & $1(9.1 \%)$ & $1(9.1 \%)$ & $4(36.4 \%)$ & \\
\hline $10-100$ & - & - & $3(27.3 \%)$ & $4(36.4 \%)$ & \\
\hline$>100$ & - & - & - & - & \\
\hline
\end{tabular}

Table 2: Overall risk-to-health Classification of drinking water sources in rural Ethiopia

\begin{tabular}{|c|c|c|c|c|c|c|c|c|}
\hline \multirow[t]{2}{*}{ Risk category } & \multicolumn{2}{|c|}{ Tap $(n=20)$} & \multicolumn{2}{|c|}{$\begin{array}{l}\text { Protected } \\
\text { dug well } \\
\mathrm{n}=11\end{array}$} & \multicolumn{2}{|c|}{$\begin{array}{l}\text { Open dug well } \\
n=11\end{array}$} & \multicolumn{2}{|c|}{$\begin{array}{c}\text { Open spring } \\
n=11\end{array}$} \\
\hline & TTC & $\mathrm{TC}$ & T'TC & $\mathrm{TC}$ & TTC & $\mathrm{TC}$ & TTC & TC \\
\hline Very low & $6(30)$ & $13(65)$ & $6(54.5)$ & - & - & - & - & - \\
\hline Low & $8(40)$ & $7(35)$ & $3(27.3)$ & $4(36.4)$ & $3(27.3)$ & - & $4(36.4)$ & - \\
\hline Medium & $2(10)$ & & $1(9.1)$ & $4(36.4)$ & $4(36.4)$ & - & $1(9.1)$ & - \\
\hline High & $4(20)$ & & $1(9.1)$ & $3(27.3)$ & $4(36.4)$ & $11(100)$ & $6(54.5)$ & $11(100)$ \\
\hline
\end{tabular}

TC, Total coliforms; TTC, Thermotolerant coliforms

The mean $\mathrm{pH}$ of tap water, protected dug well, protected spring, open dug well and open spring were $7.5 \pm 0.4,7.3 \pm 0.4,7.3 \pm 0.4,6.8 \pm 0.3$ and $6.7 \pm 0.4$, respectively. All tap and protected dug wells met national and WHO guidelines. However, $3(27.3 \%)$ and $5(45.5 \%)$ of open dug wells and open springs had $\mathrm{pH}$ values below the recommended national and WHO limits (table 3). All water samples had temperatures above $20^{\circ} \mathrm{C}$. The average temperature recorded was $22.71 \pm 1.01$ and ranged between $19.97-25.67^{\circ} \mathrm{C}$ (table 4). The minimum temperature was recorded in protected spring, whereas the maximum temperature was observed in open and protected wells. The mean turbidity values for tap water, protected dug well, protected spring, open dug well and open spring were $24.31 \pm 10.26,0.89 \pm 0.38,5.78 \pm 5.39$, $5.5 \pm 4.2$ and $1.9 \pm 9.9$, respectively. The Majority $(90 \%)$ of tap water and $72 \%$ of open hand dug well samples had turbidity values above the recommended WHO limits, whereas most of protected and open hand dug wells had turbidity values below the recommended values (table 3 ). 
Table 3: Comparison of the physico-chemical quality of four sources of water with the WHO recommended values in rural Ethiopia

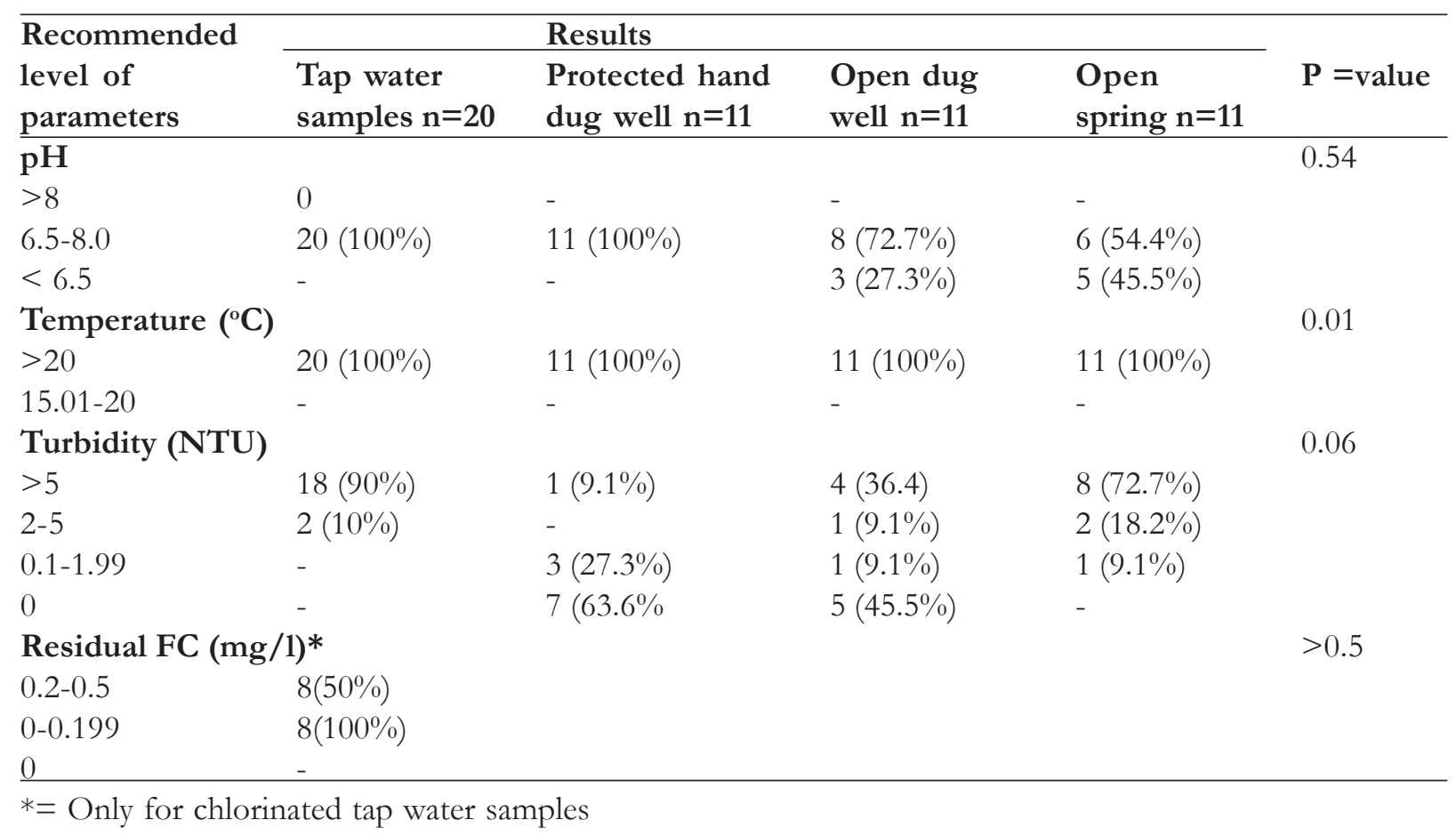

Of the 16 treated water samples analyzed, $8(50 \%)$ and $8(50 \%)$ had residual free chlorine of $2-0.5 \mathrm{mg} /$ 1 and of $0-0.199 \mathrm{mg} / \mathrm{l}$ respectively (table 3 ). The concentration of residual free chlorine in most water samples were below the recommended limit of WHO (0.2-0.5 mg/l), which indicates the inefficiency of disinfection in the distribution system.

Correlation analysis among bacteriological, physicochemical and level of risk parameters is shown in table 4.

Table 4: Correlation among bacteriological, physico-chemical and level of risk parameters

\begin{tabular}{lll}
\hline Physicochemical & \multicolumn{2}{l}{ B a c t e ri o lo g i c a 1 } \\
parameters & \multicolumn{2}{l}{ parameters } \\
\cline { 2 - 3 } & TC & TTC \\
\hline pH & $-0.52^{* *}$ & $-0.41^{* *}$ \\
Temperature & 0.09 & 0.08 \\
Conductivity & -0.06 & 0.04 \\
Turbidity & -0.15 & 0.04 \\
Residual free chlorine & -0.37 & - \\
Level of risk & $0.60^{*}$ & $0.74^{*}$ \\
\hline
\end{tabular}

$*=$ Correlation is significant at the 0.01 level

\section{Discussion}

The results of the bacteriological quality of water sources in this study concord with the results of other studies conducted in Africa ${ }^{10-12}$. The presence of significant counts of coliform bacteria in the water sources is indicative of inadequacy of the depth of the wells or a breach of sanitary integrity of the wells ${ }^{13}$. The presence of coliforms in groundwater indicates that microorganisms from surface water have been able to reach the aquifer as supported by studies of Payment and Locas ${ }^{14}$. The presence of total coliforms in tap water after disinfection indicates inadequate treatment ${ }^{3}$. There was statistically significant difference among water sources with respect to TC and TTC $(\mathrm{p}<0.05)$ where the average total coliform and thermotolerant counts were relatively higher in unprotected water sources compared to protected ones. Gwimbi ${ }^{15}$ has reported a similar finding from a study done in Lesotho.

Sanitary inspection is used to identify causes of contamination and the risks of future contamination and overall assessment maintenance and operation of water sources ${ }^{4,16}$. A study conducted in Uganda, showed that total sanitary risk score showed a significant relationship with level of contamination ${ }^{17}$. In this study, there was statistically significant positive correlation between coliform 
counts and sanitary scores $(r=0.817, \mathrm{p}<0.01)$ which is an indication for sanitary inspection's being a reliable tool for risk assessment of drinking water sources. A similar degree of correlation was reported from studies done in developing countries ${ }^{17-19}$.

Low $\mathrm{pH}$ values recorded in some open springs and dug wells may be due to saturation with carbon dioxide as indicated in other studies ${ }^{20}$. High temperature can favor the growth of organisms in water resources ${ }^{21}$. A similar study in Italy showed that the survival curves of Aeromones spp. decline rapidly at low temperature $\left(5^{\circ} \mathrm{C}\right)$, whereas survival at temperatures greater than $20^{\circ} \mathrm{C}$ increases ${ }^{22}$. There was statistically significant difference in temperature among the water sources $(p<0.05)$. Turbidity of water is an important parameter as it contributes to the aesthetics of water and leads to its acceptance or rejection for human consumption ${ }^{3,23}$.

In areas where there is little risk of a waterborne outbreak, residual free chlorine of 0.2 to $0.5 \mathrm{mg} / 1$ at all points in the supply is recommended $^{23}$. Therefore, when water leaves the treatment plant, residual free chlorine of about 1 $\mathrm{mg} / \mathrm{l}$ is needed for health reasons and it is recommended that such level should be maintained at points of consumption ${ }^{24}$. The residual free chlorine recorded in this study is supported by a case study conducted in rural areas of South Africa ${ }^{25}$. General system failures, inefficiency in disinfection and poor maintenance are some of the factors that affect the quality of water in Ethiopia ${ }^{23}$.

The high density of indicator bacteria is therefore attributed to constructional defects, poor sanitation and existence of human activities and grazing near the water sources. The risk to heath matrix of the water sources showed from high to very high risks to cause disease. The study indicates that the rural people are under severe threat to water related diseases and health risks. The continuous consumption of such polluted water could pose serious health risks especially in children, elderly and immunocompromised individuals.

\section{Conclusion}

Water sources investigated were heavily contaminated. High total coliform and thermotolerant counts and high risk scores found in the water sources suggest poor source water protection and poor sanitation conditions and practices. These findings demonstrate the need to come up with source water protection strategies for rural communities where water treatment is not available. To this end, keeping the water sources safe by properly constructed fences, regular maintenances and supervisions of water sources and proper disposal of human and animal wastes are recommended.

\section{References}

1. WHO/UNICEF. Rapid assessment drinking water quality in the Federal Democratic Republic of Ethiopia, Country Report of Pilot Project Implementation in 2004-2005.WHO, Geneva and UNICEF, New York, 2010.

2. Shyamala R, Shanthi M, Lalitha P. Physicochemical Analysis of Borewell Water Samples of Telungupalayam Area in Coimbatore District, Tamilnadu, India. E-J Chem. 2008; 5: 924 929.

3. WHO. Guidelines for Drinking-water Quality, Fourth edition. WHO, Geneva, Switzerland, 2011.

4. WHO. Water for health, WHO Guidelines for Drinking-water Quality, WHO Geneva, Switzerland 2010.

5. WHO/UNICEF. Global Water Supply and Sanitation Assessment 2000 Report, Switzerland, 2000.

6. Opisa S, Odiere MR, Jura WZO, Karanja DMS, Mwinzi PN. 2012. Water Sci Tech. 2012; 66: 2674 2681.

7. Zamxaka M, Pironcheva G, Muyima NYO. Microbiological and physico-chemical assessment of the quality of domestic water sources in selected rural communities of the Eastern Cape Province, South Africa. Water SA. 2004; 30: 333340.

8. UNICEF/WHO. Joint Monitoring report: Progress on Drinking Water and Sanitation: Special Focus on Sanitation. UNICEF, New York and WHO, Geneva, 2008.

9. American Public Health Association. Standard Methods for the Examination of Water and Wastewater. American Public Health Association, Washington, D.C. USA, 2005.

10. Admasu M, Mamo W, Baye G. A survey of bacteriological quality of drinking water in North Gondar. Ethiop J Health Develop. 2004, 18: 113115.

11. Shittu OB, Olaitan JO, Amusa TS. PhysicoChemical and Bacteriological Analyses of Water Used for Drinking and Swimming Purposes in Abeokuta, Nigeria. Afr J Biome Res. 2008; 11: 285 -290 . 
12. Parker AH, Youlton R, Dillon M, Nussbaumer T,Carter RC,Tyrrel SF, Webster J. An assessment of microbiological water quality of six water source categories in north-east Uganda. J Water Health. 2010; 8: 550-560.

13. Terngu J, Oluma A, Hyacinth OA, Sha'Ato R. Physico-chemical and Bacteriological Quality of Water from Shallow Wells in Two Rural Communities in Benue State, Nigeria. Pakistan J Anal Environ Chem. 2010; 11: 73-78.

14. Payment P, Locas, A. Pathogens in water: value and limits of correlation with microbial indicators. Ground Water. 2011; 49; 4-11.

15. Gwimbi, P. The microbial quality of drinking water in Manonyane community: Maseru District (Lesotho). Afr Health Sci. 2011; 11: 474 - 480.

16. Howard AG. Water supply surveillance: A reference manual. WEDC, Loughborough University, UK. 2002.

17. Howard G, Pedley S, Barrett M, Nalubega M, Johal K. Risk factors contributing to microbiological contamination of shallow groundwater in Kampala, Uganda. Water Res. 2003; 37: 3421-3429.

18. Lloyd B, Bartman J. Surveillance solutions to microbiological problems in water quality control in developing countries. Water Sci Technol. 1991; 24: 61-75.

19. Haruna R,Francis E, Edmond K K. The quality of water from protected springs in Katwe and Kisenyi parishes, Kampala city, Uganda. Afr Health Sci. 2005; 5: 14-20.

20. Byamukama D, Kansime F, Mach L, Farnleitner A. Determination of Escherichia coli contamination with Chromocult coliform agar showed a high level of discrimination efficiency for differing pollution levels in tropical waters of Kampala, Uganda. Appl Environ Microbiol. 1999; 66: 864868.

21. Muyima N, Ngcakani F. Indicator bacteria and regrowth potential of the drinking water in Alice, Eastern Cape. Dep J Biochem Microbiol. 1998, 24: 29-34.

22. Sisti M, Albaino A, Brandi G. Bacteriological effect of chlorine on motile Aeromonas spp. in drinking water supplies and influence of temperature on disinfection efficiency. Appl Microbiol, 1998; 26: 347-351.

23. Dagnew T, Assefa D, Woldemariam G, Solomon F, Schmoll O. Rapid Assessment of Drinking-Water Quality in the Federal Republic of Ethiopia. Federal Democratic republic of Ethiopia, Ministry of Health, Environmental health Department. Country report. Addis Ababa, 19-67. 2007.

24. Momba MB, Tyafa Z, Makala N, Brouckaert BM, Obi CL. Safe drinking water stills a dream in rural areas of South Africa. Case Study: The Eastern Cape Province. Water SA. 2006; 32: 715722.

25. Gundry SW, Wright JA, Conroy R, Du Preez M, Genthe B, Moyo S. Contamination of drinking water between source and point-of-use in rural households of South Africa and Zimbabwe: implications for monitoring the Millennium Development Goal for water. J Water Prac Tech. 2006; 1:1-9. 